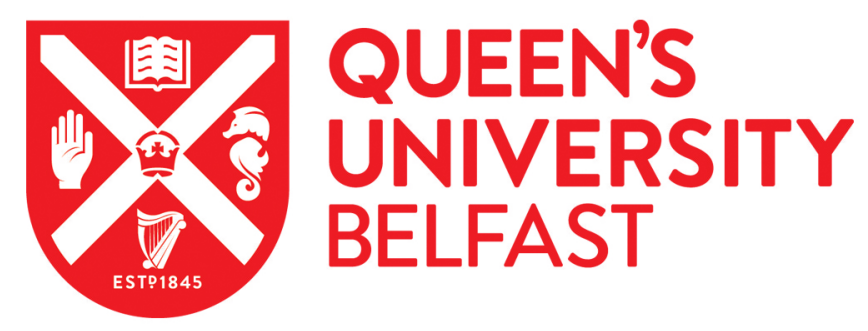

\title{
Structural effects on the pH-dependent fluorescence of naphthalenic derivatives and consequences for sensing/switching
}

Zheng, S., Lynch, P. L. M., Rice, T. E., Moody, T. S., Gunaratne, H. Q. N., \& De Silva, A. P. (2012). Structural effects on the $\mathrm{pH}$-dependent fluorescence of naphthalenic derivatives and consequences for sensing/switching. Photochemical \& Photobiological Sciences, 11(11), 1675-1681. https://doi.org/10.1039/C2PP25069A

Published in:

Photochemical \& Photobiological Sciences

Document Version:

Peer reviewed version

Queen's University Belfast - Research Portal:

Link to publication record in Queen's University Belfast Research Portal

Publisher rights

(C) The Royal Society of Chemistry and Owner Societies 2012

\section{General rights}

Copyright for the publications made accessible via the Queen's University Belfast Research Portal is retained by the author(s) and / or other copyright owners and it is a condition of accessing these publications that users recognise and abide by the legal requirements associated with these rights.

Take down policy

The Research Portal is Queen's institutional repository that provides access to Queen's research output. Every effort has been made to ensure that content in the Research Portal does not infringe any person's rights, or applicable UK laws. If you discover content in the Research Portal that you believe breaches copyright or violates any law, please contact openaccess@qub.ac.uk. 


\title{
Structural Effects on the pH-dependent Fluorescence of Naphthalenic Derivatives and Consequences for Sensing/Switching
}

\author{
Shuai Zheng, P. L. Mark Lynch, Terence E. Rice, Thomas S. Moody, H. Q. Nimal \\ Gunaratne and A. Prasanna de Silva
}

School of Chemistry and Chemical Engineering, Queen's University, Belfast BT9 $5 A G$, Northern Ireland.

E-mail: a.desilva@qub.ac.uk.Phone: +44 2890 974422. Fax: +44 2890974890

Dedicated to Jean-Pierre Desvergne and to Hubert Le Bozec

\begin{abstract}
Naphthalenic compounds are a rich resource for designers of fluorescent sensing/switching/logic systems. The degree of ICT character in the fluorophore excited states can vary from negligible to substantial. Naphthalene-1,8;4,5-diimides (11-13), 1,8-naphthalimides (16) and 4-chloro-1,8-naphthalimides (15) are of the former type. The latter type is represented by the 4-alkylamino-1,8-naphthalimides (1). Whether ICT-based or not, these serve as the fluorophore in 'fluorophore-spacerreceptor' switching systems where PET holds sway until the receptor is bound to $\mathrm{H}^{+}$. On the other hand, 4-dialkylamino-1,8-naphthalimides (3-4) show modest $\mathrm{H}^{+}$-induced fluorescence switching unless the 4-dialkylamino group is a part of a small ring (5). Electrostatic destabilization of a non-emissive twisted ICT excited state is the origin of this behaviour. An evolution to the non-emissive twisted ICT excited state is responsible for the weak emission of the model compound $\mathbf{6}$ (and related structures $\mathbf{7}$ and 8) across the $\mathrm{pH}$ range. Twisted ICT excited states are also implicated in the switch 9 and its model compound 10, which are based on the 6-dialkylamino-3Hbenzimidazo[2,1-a]benz[d,e]isoquinolin-3-one fluorophore.
\end{abstract}

\section{Introduction}

Naphthalimides and related compounds ${ }^{1}$ have found much use in the fluorescent sensing/switching sphere. ${ }^{2-25}$ Some have featured as molecular logic gates. ${ }^{26-37}$ Others have even found commercial success in blood electrolyte diagnostics. ${ }^{38-41}$ Beside convenient synthetic routes, these compounds have very useful optical and redox properties which lead to the above applications. Compound $\mathbf{1}^{2}$ is a well-behaved fluorescent PET (photoinduced electron transfer) system ${ }^{42-45}$ of the 'fluorophorespacer-receptor' format, ${ }^{46,47}$ whose fluorescence responds sharply to $\mathrm{H}^{+}$. Briefly, the diethylamino receptor launches an electron to the photoexcited fluorophore so that fluorescence is quenched. Upon binding $\mathrm{H}^{+}$to the diethylamino receptor, this PET pathway is arrested so that fluorescence emerges. The photogenerated electric field of the ICT (internal charge transfer) excited state of the aminonaphthalimide fluorophore contributes to the PET efficiency. ${ }^{2}$ This leads conceptually to the mimicry of the pathselective PET in the bacterial photosynthetic reaction centre ${ }^{6,25}$ and to the development of fluorescent PET systems for neural signalling. ${ }^{48}$ Now we examine several structural variations on $\mathbf{1}$, some of which have major influences on $\mathrm{pH}$ dependent fluorescence behaviour.

\section{Experimental}




\section{Materials}

N-Butyl-4-chloro-1,8-naphthalimide (2)

4-Chloro-1,8-naphthalic anhydride (2.9 g. 12.5 mmol), n-butylamine (0.9 g, 12.5 $\mathrm{mmol})$ and toluene $(30 \mathrm{ml})$ were refluxed for $4 \mathrm{hr}$. The solvent was distilled off under vacuum. Crystallization from acetic acid gave pale yellow crystals. Yield 60\%, m.p. 180-181 C. Found: $\mathrm{M}^{+}=287.0801 . \mathrm{C}_{16} \mathrm{H}_{14} \mathrm{NO}_{2} \mathrm{Cl}$ requires 287.0713; $\delta_{\mathrm{H}}\left(\mathrm{CDCl}_{3}\right)$ 7.968.59 (m, 5H, ArH), 4.05 (t, 2H, NCH$)_{2}, 1.57$ (m, 2H, NCH $\left.\mathrm{CH}_{2}\right), 1.30$ (m, 2H, $\left.\mathrm{MeCH}_{2}\right), 0.89$ (t, $\left.3 \mathrm{H}, \mathrm{CH}_{3}\right)$.

N-Butyl-4-[N'-methyl-2'-(N",N"-diethylamino)ethyl] amino-1,8-naphthalimide (3) Compound 2 (1.0 g. $3.5 \mathrm{mmol}$ ) was dissolved in N,N-diethyl-N'methylethylenediamine ( $4.5 \mathrm{~g}, 35 \mathrm{mmol})$ and heated at $100 \mathrm{C}$ for $4 \mathrm{hr}$. The mixture was evaporated to dryness under vacuum. Crystallization from diethylether/hexane gave yellow plates. Yield 68\%, m.p. 147-149 C. Found: $\mathrm{M}+\mathrm{H}^{+}=382.2495$. $\mathrm{C}_{23} \mathrm{H}_{32} \mathrm{~N}_{3} \mathrm{O}_{2}$ requires 382.2495; $\delta_{\mathrm{H}}\left(\mathrm{CDCl}_{3}\right)$ 7.33-8.62 (m, 5H, $\left.\mathrm{ArH}\right), 4.17(\mathrm{t}, 2 \mathrm{H}$, $\mathrm{OCNCH}_{2}$ ), 3.93 (t, 2H, ArNCH 2 ), 3.17-3.23 (brm, 6H, $\mathrm{MeCH}_{2} \mathrm{~N}$ and $\mathrm{Et}_{2} \mathrm{NCH}_{2}$ ), 3.12

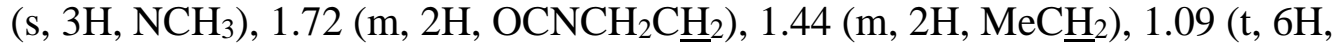
$\left.\mathrm{NCH}_{2} \underline{\mathrm{CH}}_{3}\right), 0.97$ (t, $\left.3 \mathrm{H}, \mathrm{CH}_{2} \underline{\mathrm{CH}}_{3}\right)$.

$N$-Butyl-4-[N'-methyl-2'-( $N$ ", $N$ "-dimethylamino)ethyl] amino-1,8-naphthalimide (4) Compound $\mathbf{4}$ was prepared according to a procedure analogous to that used for $\mathbf{3}$, except that N,N-diethyl-N'-methylethylenediamine was replaced with N,N,N'trimethylethylenediamine. Crystallization from diethylether/hexane gave orange crystals. Yield 62\%, m.p. 138-139 C. Found: $\mathrm{M}+\mathrm{H}^{+}=354.2062 . \mathrm{C}_{21} \mathrm{H}_{28} \mathrm{~N}_{3} \mathrm{O}_{2}$ requires 354.2181; $\delta_{\mathrm{H}}\left(\mathrm{CDCl}_{3}\right)$ 7.27-8.59 (m, 5H, ArH), 4.17 (t, 2H, $\left.\mathrm{OCNCH}_{2}\right), 3.97$ (t, 2H, $\mathrm{ArNCH}_{2}$ ), 3.22 (s, 6H, N(CH3) $\left.)_{2}\right), 3.19$ (t, 2H, $\left.\mathrm{Me}_{2} \mathrm{NCH}_{2}\right), 3.14$ (s, 3H, $\left.\mathrm{NCH}_{3}\right), 1.70$ (m, 2H, OCNCH${ }_{2} \underline{\mathrm{H}}_{2}$ ), 1.44 (m, 2H, $\mathrm{MeC}_{2}$ ), 1.01 (t, 6H, $\left.\mathrm{NCH}_{2} \underline{\mathrm{C}}_{3}\right), 0.97$ (t, 3H, $\left.\mathrm{CH}_{2} \underline{\mathrm{C}}_{3}\right)$.

$N$-Butyl-4-N'-methylpiperazino-1,8-naphthalimide (5)

Compound 5 was prepared according to a procedure analogous to that used for $\mathbf{3}$, except that N,N-diethyl-N'-methylethylenediamine was replaced with $\mathrm{N}$ -

methylpiperazine. Crystallization from ethanol gave bright orange crystals. Yield 11\%, m.p. 118-119 C. Found: C, 71.5; $\mathrm{H}, 6.9 ; \mathrm{N}, 11.7 . \mathrm{C}_{21} \mathrm{H}_{25} \mathrm{~N}_{3} \mathrm{O}_{2}$ requires $\mathrm{C}$, 71.8; $\mathrm{H}, 7.2$; $\mathrm{N}, 11.9 \% ; \delta_{\mathrm{H}}\left(\mathrm{CDCl}_{3}\right) 7.24-8.59(\mathrm{~m}, 5 \mathrm{H}, \mathrm{ArH}), 4.17\left(\mathrm{t}, 2 \mathrm{H}, \mathrm{OCNCH}_{2}\right), 3.30(\mathrm{t}, 4 \mathrm{H}$, $\mathrm{ArNCH}_{2}$ ), 2.74 (t, 4H, MeNCH 2$), 2.47$ (s, 3H, NCH 3$), 1.70$ (m, 2H, $\mathrm{OCNCH}_{2} \mathrm{CH}_{2}$ ),

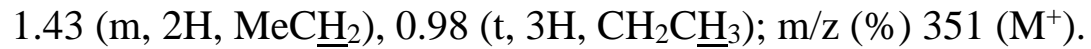

N-Butyl-4-morpholino-1,8-naphthalimide (6)

Compound $\mathbf{6}$ was prepared according to a procedure analogous to that used for $\mathbf{5}$, except that $\mathrm{N}$-methylpiperazine was replaced with morpholine. Crystallization from ethanol gave yellow crystals. Yield 36\%, m.p. 124-125 C. Found: C, 71.1; H, 6.5; N, 8.3. $\mathrm{C}_{20} \mathrm{H}_{22} \mathrm{~N}_{2} \mathrm{O}_{3}$ requires $\mathrm{C}$, 71.0; $\mathrm{H}, 6.6 ; \mathrm{N}, 8.3 \% ; \delta_{\mathrm{H}}\left(\mathrm{CDCl}_{3}\right)$ 8.61-7.24 (m, 5H, $\mathrm{ArH}), 4.17$ (t, 2H, OCNCH 2$), 4.02$ (t, 4H, $\left.\mathrm{ArNCH}_{2}\right), 3.26$ (t, 4H, OCH $), 1.70$ (m, 2H,

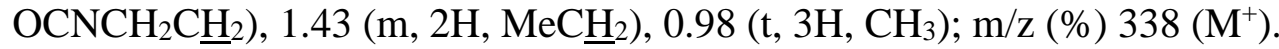

$N$-2'-(N',N'-diethylamino)ethyl-4-morpholino-1,8-naphthalimide (7)

Compound 7 was prepared according to a procedure analogous to that used for $\mathbf{6}$, except that 2 was replaced with $\mathrm{N}-2$ '-(diethylamino)ethyl-4-chloro-1,8naphthalimide. ${ }^{5}$ Crystallization from diethylether/methanol gave yellow-orange 
crystals. Yield 26\%, m.p. 123-124 C. Found: C, 69.1; H, 7.3; N, 11.0. $\mathrm{C}_{22} \mathrm{H}_{27} \mathrm{~N}_{3} \mathrm{O}_{3}$ requires $\mathrm{C}, 69.3 ; \mathrm{H}, 7.1 ; \mathrm{N}, 11.0 \% ; \delta_{\mathrm{H}}\left(\mathrm{CDCl}_{3}\right) 7.25-8.57(\mathrm{~m}, 5 \mathrm{H}, \mathrm{ArH}), 4.28(\mathrm{t}, 2 \mathrm{H}$, $\mathrm{OCNCH}_{2}$ ), 4.02 (t, 4H, OCH ${ }_{2}$ ), 3.26 (t, 4H, $\mathrm{ArNCH}_{2}$ ), 2.80 (t, $2 \mathrm{H}, \mathrm{OCNCH}_{2} \underline{\mathrm{C}}_{2}$ ),

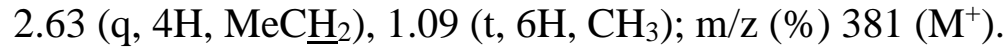

N-2'-(morpholino)ethyl-4-morpholino-1,8-naphthalimide (8)

Compound 8 was prepared according to a procedure analogous to that used for $\mathbf{6}$, except that 2 was replaced with $\mathrm{N}$-2'-(morpholino)ethyl-4-chloro-1,8-naphthalimide. ${ }^{5}$ Crystallization from chlorobenzene gave bright yellow crystals. Yield 33\%, m.p. 196197 C. Found: C, 66.8; H, 6.2; N, 10.3. $\mathrm{C}_{22} \mathrm{H}_{25} \mathrm{~N}_{3} \mathrm{O}_{4}$ requires $\mathrm{C}, 66.8 ; \mathrm{H}, 6.4 ; \mathrm{N}$, $10.6 \% ; \delta_{\mathrm{H}}\left(\mathrm{CDCl}_{3}\right) 7.26-8.59(\mathrm{~m}, 5 \mathrm{H}, \mathrm{ArH}), 4.35\left(\mathrm{t}, 2 \mathrm{H}, \mathrm{OCNCH}_{2}\right), 4.02(\mathrm{t}, 4 \mathrm{H}$, $\mathrm{ArNCH}_{2} \mathrm{CH}_{2}$ ), 3.65 (t, 4H, $\left.\mathrm{CH}_{2} \mathrm{NCH}_{2} \underline{\mathrm{CH}}_{2} \mathrm{O}\right), 3.24$ (t, 4H, $\left.\mathrm{ArNCH}_{2}\right), 2.72$ (t, 2H, $\left.\mathrm{OCNCH}_{2} \underline{\mathrm{C}}_{2}\right), 2.57$ (t, 4H, $\left.\mathrm{CH}_{2} \mathrm{NC}_{2} \mathrm{CH}_{2} \mathrm{O}\right) ; \mathrm{m} / \mathrm{z}(\%) 395\left(\mathrm{M}^{+}\right)$.

6-N'-Methylpiperazino-3H-benzimidazo[2,1-a]benz[d,e] isoquinolin-3-one (9) 6-Chloro-3H-benzimidazo[2,1-a]benz[d,e]isoquinolin-3-one (3.2 g. $0.01 \mathrm{~mol}),{ }^{49,50} \mathrm{~N}$ methylpiperazine ( $9 \mathrm{ml}, 0.08 \mathrm{~mol})$, hydrated $\mathrm{CuSO}_{4}(0.4 \mathrm{~g}, 1.6 \mathrm{mmol})$ and 2methoxyethanol $(100 \mathrm{ml})$ were refluxed for $6 \mathrm{hr}$. The reaction mixture was poured into water to give the crude product. This was dissolved in $\mathrm{HCl}(0.1 \mathrm{M})$, washed with $\mathrm{CH}_{2} \mathrm{Cl}_{2}$, basified with $\mathrm{NaOH}$ and extracted into $\mathrm{CH}_{2} \mathrm{Cl}_{2}$ and the solvent evaporated off. Crystallization from $\mathrm{CH}_{2} \mathrm{Cl}_{2}$ gave bright orange crystals. Yield 20\%, m.p. 235-236 C. Found: C, 74.7; $\mathrm{H}, 5.3 ; \mathrm{N}, 14.9 . \mathrm{C}_{23} \mathrm{H}_{20} \mathrm{~N}_{4} \mathrm{O}$ requires $\mathrm{C}, 75.0 ; \mathrm{H}, 5.5 ; \mathrm{N}, 15.3 \%$; $\delta_{\mathrm{H}}\left(\mathrm{CDCl}_{3}\right)$ 7.22-8.78 (m, 9H, ArH), 3.35 (t, 4H, $\left.\mathrm{ArNCH}_{2}\right), 2.65$ (t, 4H, $\mathrm{MeNCH}_{2}$ ), $2.46\left(\mathrm{~s}, 3 \mathrm{H}, \mathrm{NCH}_{3}\right) ; \mathrm{m} / \mathrm{z}(\%) 368\left(\mathrm{M}^{+}\right)$.

6-Morpholino-3H-benzimidazo[2,1-a]benz[d,e]isoquinolin-3-one (10) Compound $\mathbf{1 0}$ was prepared according to a procedure analogous to that used for $\mathbf{9}$, except that $\mathrm{N}$-methylpiperazine was replaced with morpholine. Also, the acidification/basification routine was not used. Crystallization from chlorobenzene gave bright orange crystals. Yield 44\%, m.p. 228-232 C. Found: $\mathrm{M}^{+}=355.1319$. $\mathrm{C}_{22} \mathrm{H}_{17} \mathrm{~N}_{3} \mathrm{O}_{2}$ requires 355.1319; $\delta_{\mathrm{H}}\left(\mathrm{CDCl}_{3}\right)$ 7.24-8.78 (m, 9H, $\left.\mathrm{ArH}\right), 4.01(\mathrm{t}, 4 \mathrm{H}$, $\mathrm{OCH}_{2}$ ), 3.22 (t, 4H, $\mathrm{NCH}_{2}$ ).

$N, N$ '-bis [(2'-( $N$ ", $N$ ”-dimethylamino)ethyl]-1,8;4,5-naphthalenediimide (11) 1,8;4,5-Naphthalenetetracarboxylic dianhydride (3.4 g. $12.5 \mathrm{mmol}$ ), N,Ndimethylethylenediamine $(2.2 \mathrm{~g}, 25 \mathrm{mmol})$ and toluene $(50 \mathrm{ml})$ was refluxed for $4 \mathrm{hr}$. The mixture was evaporated to dryness under vacuum and washed with acetone to give an orange solid. Yield 65\%, m.p. 272-274 C (lit. ${ }^{51}$ m.p. 279-281). Found: C, 64.1; $\mathrm{H}, 5.7 ; \mathrm{N}, 13.5 . \mathrm{C}_{22} \mathrm{H}_{24} \mathrm{~N}_{4} \mathrm{O}_{4}$ requires $\mathrm{C}, 64.7 ; \mathrm{H}, 5.9 ; \mathrm{N}, 13.7 \% ; \delta_{\mathrm{H}}\left(\mathrm{CDCl}_{3}\right) 8.74$ (s, 4H, ArH), 4.34 (t, 4H, OCNCH ${ }_{2}$ ), 2.67 (t, 4H, $\mathrm{Me}_{2} \mathrm{NCH}_{2}$ ), 2.34 (s, 12H, $\mathrm{NCH}_{3}$ ); $\mathrm{m} / \mathrm{z} 408\left(\mathrm{M}^{+}\right)$.

$N, N$ '-bis [(2'-(morpholino)ethyl]-1,8;4,5-naphthalenediimide (12)

Compound 12 was prepared according to a procedure analogous to that used for $\mathbf{1 1}$, except that N,N-dimethylethylenediamine was replaced with 4-(2'amino)ethylmorpholine. Orange solid. Yield 65\%, m.p. 220-221 C. Found: $\mathrm{M}^{+}=$ 492.2024. $\mathrm{C}_{26} \mathrm{H}_{28} \mathrm{~N}_{4} \mathrm{O}_{6}$ requires 492.2009; $\delta_{\mathrm{H}}\left(\mathrm{CDCl}_{3}\right) 8.77$ (s, $\left.4 \mathrm{H}, \mathrm{ArH}\right), 4.37$ (t, 4H, $\mathrm{OCNCH}_{2}$ ), 3.65 (t, 8H, NCH${ }_{2} \underline{\mathrm{H}}_{2} \mathrm{O}$ ), 2.71 (s, 4H, $\mathrm{OCNCH}_{2} \underline{\mathrm{CH}}_{2}$ ), 2.58 (bm, 8H, $\mathrm{NC}_{2} \mathrm{CH}_{2} \mathrm{O}$ ). 
$N, N$ '-bis [(3'-(N”,N”-dimethylamino)propyl]-1,8;4,5-naphthalenediimide (13)

Compound $\mathbf{1 3}$ was prepared according to a procedure analogous to that used for $\mathbf{1 1}$, except that N,N-dimethylethylenediamine was replaced with $\mathrm{N}, \mathrm{N}-$

dimethylpropylenediamine. Orange solid. Yield 63\%, m.p. 263-264 C. Found: C, 61.3; $\mathrm{H}, 5.9 ; \mathrm{N}, 11.9 . \mathrm{C}_{24} \mathrm{H}_{28} \mathrm{~N}_{4} \mathrm{O}_{4}$ requires $\mathrm{C}, 61.0 ; \mathrm{H}, 5.9 ; \mathrm{N}, 11.9 \% ; \delta_{\mathrm{H}}\left(\mathrm{CDCl}_{3}\right) 8.74$ (s, 4H, ArH), 4.26 (t, 4H, $\mathrm{OCNCH}_{2}$ ), 2.44 (t, 4H, $\mathrm{Me}_{2} \mathrm{NC}_{2}$ ), 2.34 (s, 12H, $\mathrm{NCH}_{3}$ ), 1.92 (q, 4H, OCNCH$\left.{ }_{2} \underline{\mathrm{H}}_{2}\right) ; \mathrm{m} / \mathrm{z} 436\left(\mathrm{M}^{+}\right)$.

\section{Equipment and methods}

UV-Visible absorption and fluorescence emission spectra were recorded on PerkinElmer Lambda 9 and Perkin-Elmer LS-55/LS5B spectrometers, respectively. Nuclear magnetic resonance spectra were obtained with a Bruker AC250 spectrometer. Mass spectra were obtained with a VG MS902 instrument. pH measurements employed a Jenway $3310 \mathrm{pH}$ meter with a glass electrode.

\section{Results and discussion}

The important parameters which characterize the $\mathrm{H}^{+}$-induced fluorescence switching action of $\mathbf{1}$ have been published ${ }^{2}$ and are summarized in Table 1 . Compound $\mathbf{1}$ is strongly emissive in acid media $\left(\phi_{\text {Flu.acid }}=0.76\right)$ but is quenched by a factor of 25 in base. Notably, acid media induce a $18 \mathrm{~nm}$ blue-shift in the absorption spectrum due to destabilization of the Franck-Condon ICT excited state by the neighbouring protonated amine receptor. A similar effect is discernible regarding the thermally equilibriated ICT excited state in the fluorescence emission spectra.

Table 1. Various parameters for 1-10 (except 2) determined via pH-dependent uvvisible absorption and fluorescence spectroscopy. ${ }^{\mathrm{a}}$

\begin{tabular}{|c|c|c|c|c|c|c|c|c|c|}
\hline Parameter & 1 & 3 & 4 & 5 & 6 & 7 & 8 & 9 & 10 \\
\hline$\lambda_{\text {Abs.acid }}$ & 431 & 399 & 398 & 387 & 402 & 403 & 404 & 411 & 416 \\
\hline $\log \varepsilon_{\text {acid }}{ }^{b}$ & 4.22 & 4.14 & 4.32 & 4.14 & 4.01 & 4.07 & 4.04 & 4.30 & 4.03 \\
\hline$\lambda_{\text {Abs.base }}$ & 449 & 439 & 439 & 405 & 402 & 402 & 402 & 427 & 416 \\
\hline $\log \varepsilon_{\text {base }} \mathrm{b}$ & 4.22 & 4.14 & 4.32 & 4.08 & 4.01 & 4.04 & 4.04 & 4.30 & 4.03 \\
\hline$\lambda_{\text {Isosbestic }}$ & 440 & 414 & 416 & 404 & $-{ }^{h}$ & $-{ }^{h}$ & $-{ }^{\mathrm{h}}$ & 416 & $-{ }^{h}$ \\
\hline $\mathrm{pK}_{\mathrm{a}}^{\mathrm{c}}$ & 8.4 & 8.9 & 8.3 & 7.4 & $-\mathrm{h}$ & $-\mathrm{h}$ & $-\mathrm{h}$ & 7.3 & $-\mathrm{h}$ \\
\hline$\lambda_{\text {Flu.acid }}$ & 538 & 531 & 528 & 520 & 538 & $540^{j}$ & $540^{1}$ & 500 & 545 \\
\hline$\phi_{\text {Flu.acid }}{ }^{\mathrm{d}}$ & 0.76 & 0.031 & 0.033 & 0.58 & 0.006 & 0.004 & 0.006 & 0.55 & 0.044 \\
\hline$\lambda_{\text {Flu.base }}$ & 549 & 530 & 527 & $-g$ & 538 & $540^{j}$ & $540^{1}$ & $-g$ & 545 \\
\hline$\phi_{\text {Flu.base }}{ }^{\mathrm{d}}$ & 0.030 & 0.011 & 0.010 & 0.001 & 0.006 & 0.005 & 0.007 & 0.003 & 0.042 \\
\hline $\mathrm{FE}^{\mathrm{e}}$ & 25 & 2.8 & 3.3 & 480 & 1.1 & $0.9^{\mathrm{k}}$ & $0.9^{\mathrm{m}}$ & 200 & 1.0 \\
\hline $\mathrm{pK}_{\mathrm{a}}{ }^{\prime}{ }^{\mathrm{f}}$ & 8.7 & 8.7 & 8.1 & 7.2 & $\mathrm{-i}^{\mathrm{i}}$ & 8.5 & 6.0 & 7.3 & $-{ }^{\mathrm{i}}$ \\
\hline
\end{tabular}

a. $10^{-5} \mathrm{M}$ in methanol:water $(1: 4, \mathrm{v} / \mathrm{v})$. Fluorescence emission spectra are obtained by excitation at $\lambda_{\text {Isosbestic. }}$ The subscripts 'acid' and 'base' in some of the parameters refer to the limiting value of a given parameter when the acid or base condition is increased respectively. Data for compound $\mathbf{1}$ is from ref. 2.

b. $\varepsilon$ in $\mathrm{M}^{-1} \mathrm{~cm}^{-1}$.

c. obtained by analyzing the $\mathrm{pH}$ dependence of the Absorbance $(\mathrm{A})$ at a given wavelength according to the equation $\log \left[\left(\mathrm{A}_{\mathrm{acid}}-\mathrm{A}\right) /\left(\mathrm{A}-\mathrm{A}_{\text {base }}\right)\right]=\mathrm{pH}-\mathrm{pK}_{\mathrm{a}} \cdot{ }^{52,53}$ Uncertainty $=0.1$.

d. uncertainty $=0.001$ or $10 \%$ whichever is the larger.

e. $\mathrm{H}^{+}$-induced fluorescence enhancement factor $=\phi_{\text {Flu.acid }} / \phi_{\text {Flu.base }}$. 
f. obtained by analyzing the $\mathrm{pH}$ dependence of the fluorescence intensity ( $\mathrm{I}_{\mathrm{Flu}}$ ) or fluorescence quantum yield $\left(\phi_{\text {Flu }}\right)$ at a given wavelength according to the equation $\log \left[\left(\phi_{\text {Flu.acid }}-\phi_{\text {Flu }}\right) /\left(\phi_{\text {Flu }}-\phi_{\text {Flu.base }}\right)\right]=\mathrm{pH}-$ $\mathrm{pK}_{\mathrm{a}}{ }^{.54}$ Uncertainty $=0.1$.

g. indeterminable owing to the low value of $\phi_{\text {Flu.base }}$.

$\mathrm{h}$. indeterminable owing to the lack of an analyzable dependence of absorbance on $\mathrm{pH}$.

i. indeterminable owing to the lack of an analyzable dependence of fluorescence on $\mathrm{pH}$.

j. shoulder at $476 \mathrm{~nm}$.

k. $\left(\mathrm{I}_{\text {Flu.acid }} / \mathrm{I}_{\text {Flu.base }}\right)_{476 \mathrm{~nm}}=2.1$.

l. shoulder at $481 \mathrm{~nm}$.

m. $\left(\mathrm{I}_{\text {Flu.acid }} / \mathrm{I}_{\text {Flu.base }}\right)_{476 \mathrm{~nm}}=2.0$.

Replacing the hydrogen at the 4-amino group of $\mathbf{1}$ by a methyl gives compound $\mathbf{3}$. While 3 contains a diethylamino receptor, its sibling 4 carries a dimethylamino receptor instead. The $\mathrm{H}^{+}$-induced absorption spectral blue-shifts seen for $3(40 \mathrm{~nm})$

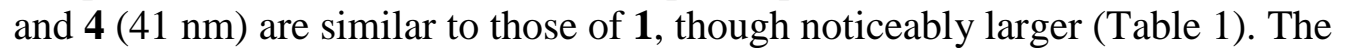
fluorescence emission spectra of $\mathbf{4}$ (Figure 1) display a $\mathrm{H}^{+}$-induced fluorescence enhancement factor (FE) of just 3.3. Even more crucially, the fluorescence quantum yield in acid is only 0.033 . Thus, protonation does not kill off the major channel(s) of excited state deactivation. $\mathrm{H}^{+}$-induced PET suppression plays a minor role, if at all.

Converting the 4-monoalkylamino group of $\mathbf{1}$ into the 4-dialkylamino group of $\mathbf{3}$ and 4 causes steric hindrance with the peri-hydrogen at the 5-position unless relieved by twisting about the aromatic C-N bond. Such twisting, and the resulting reduction of $\pi$ conjugation, is mirrored in lower absorption spectral wavelengths $\left(\lambda_{\text {Abs.base }}=439 \mathrm{~nm}\right.$ for 3 and 4 c.f. $449 \mathrm{~nm}$ for 1). Lower ICT-type emission spectral wavelengths (Table 1) also support this conclusion. An extreme case of twisting about naphthalenic C-N bonds due to steric hindrance is seen in the proton sponge behaviour of 1,2bis(dimethylamino)naphthalene. ${ }^{55}$

ICT excited states which can twist about aromatic C-N bonds lead to TICT (twisted intramolecular charge transfer) excited states. ${ }^{56-58}$ Though emissive cases are in the minority, these states lead to deexcitation pathways in many flexible fluorophores. ${ }^{57,58}$ Such twisted ICT excited states undergo deconjugation between electron-donor and acceptor segments so that full charge separation occurs, with suitable stabilization by polar solvents. The thermodynamics of such processes are very similar to those seen in PET systems. ${ }^{56-59}$ Pre-twisting in the ground state leads to an extra propensity for twisted ICT excited state formation. ${ }^{57,58}$ This situation applies to observations regarding compounds $\mathbf{3}$ and $\mathbf{4}$ in their basic form, with the dialkylamino unit and the naphthalimide moiety serving as the donor and acceptor of the twisted ICT state respectively. An approximate valence bond representation is shown in structure 14. A characteristic emission would be good evidence of twisted ICT states but this has been seen in only a small minority of these cases. ${ }^{56-58}$ So it is not surprising that we failed to see any such evidence with our basic spectrometers.

When the diethyl- or dimethyl-aminoethyl side-chains are protonated, the new cationic charge is positioned two methylene groups away from the radical cation centre of the twisted ICT excited state. Naturally, this electrostatic destabilization of the twisted ICT state reduces the efficiency of this deexcitation channel. Hence, the $\mathrm{H}^{+}$-induced FE value of 3.3 which is seen for $\mathbf{4}$ (Figure 1), for instance, is understandable. 
Case 5, incorporating a piperazine ring into the dialkylamino donor portion of the twisted ICT state, takes the effect to an extreme. When compared to 3, compound 5 suffers an even lower value of $\lambda_{\text {Abs.base }}(405 \mathrm{~nm}$ for 5 c.f. $439 \mathrm{~nm}$ for 3 ). Thus the pretwisting in the ground state is greater for $\mathbf{5}$, due to reduced flexibility of the piperazine ring c.f. the alkyl chain in $\mathbf{3}$. So it is not surprising that the twisted ICT process is the strongest and the fluorescence of 5 is the weakest $\left(\phi_{\text {Flu.base }}=0.001\right)$ seen in this work. However, protonation of 5 gives a dramatic fluorescence enhancement $(\mathrm{FE}=480)$ and the $\phi$ Fluacid value of 0.58 is the highest observed in the present experimental work. Even though the new cationic charge is still positioned two methylene groups away from the radical cation centre of the twisted ICT state, the piperazine ring forces the separation distance to be smaller. Therefore the electrostatic destabilization of the twisted ICT state is stronger. In this situation, the N-C-C-N atom set involves a gauche arrangement of the two $\mathrm{C}-\mathrm{N}$ bonds. In contrast, protonated and excited 3 involves an antiperiplanar arrangement which reduces the electrostatic repulsion as far as possible. It is worth noting that, from an operational viewpoint, compound $\mathbf{5}$ behaves like a classical fluorescent PET sensor ${ }^{60}$ for $\mathrm{H}^{+}$even though a careful structure-activity analysis reveals a twisted ICT state at work. During their extensive studies, Tian et al examined a structure which is $\mathbf{5}$ but with a methyl instead of the nbutyl group at the imide position and attributed a PET mechanism to it. ${ }^{61}$ Other cases in the literature which may have been assigned too hurriedly as fluorescent PET sensors can be investigated in this way.

When the $\mathbf{N}$-methylpiperazine ring in $\mathbf{5}$ is mutated to a morpholine, we get compound $\mathbf{6}$ which can serve as a model fluorophore for 3, $\mathbf{4}$ and particularly, 5. Indeed, compounds $\mathbf{5}$ and $\mathbf{6}$ possess essentially identical electronic absorption spectra in basic solution (e.g. $\lambda_{\text {Abs.base }}$ values differ by only $3 \mathrm{~nm}$ ). Lacking an amine side-chain, 6 naturally shows $\mathrm{pH}$-independent photoproperties. It is most telling that $\mathbf{6}$ has a weak fluorescence $\left(\phi_{\text {Flu }}=0.006\right)$. The deactivation of the emissive ICT state due to twisted ICT state evolution is clearly displayed here.

Compounds $\mathbf{7}$ and $\mathbf{8}$ give us the opportunity to test electrostatic perturbations of the twisted ICT excited state from the opposite end of the $\pi$-electron system. Related studies in systems lacking twisting, e.g. 1 and its regioisomers, led to the control of PET rates by internal electric fields ${ }^{2,15}$ and by the presence of nodes in frontier orbitals. ${ }^{62,15}$ When the diethylamino- or morpholino-ethyl side-chains are protonated, the new cationic charge is again positioned two methylene groups away from the edge of the twisted ICT excited state. However, this edge carries only a fraction of the radical anionic charge spread over the naphthalimide frame. Thus the electrostatic effect, which should be a stabilization in this case, on the twisted ICT state is much smaller than those seen in $\mathbf{3}$ and $\mathbf{4}$. Hence, the weak fluorescence is essentially pHindependent (Table 1) even though $\mathrm{pK}_{\mathrm{a}}$ ' values can be coaxed from the emission spectra.

Compounds 5 and 6 can be mutated further into 6-amino-3H-benzimidazo[2,1a]benz[d,e]isoquinolin-3-one derivatives $\mathbf{9}$ and $\mathbf{1 0}$ respectively by altering the imide functionality. Versions of these which are of the 'ICT fluorophore-spacer-receptor' type have been discussed previously. ${ }^{63}$ Model fluorophore $\mathbf{1 0}$ has a weak and $\mathrm{pH}$ independent fluorescence $\left(\phi_{\text {Flu.acid }}=0.044\right)$ which indicates the energy-sapping twisted ICT evolution at work. The latter originates from the pretwisting about the aromatic $\mathrm{C}-\mathrm{N}$ bond near the morpholino unit. Piperazino-based 9 produces a $\mathrm{H}^{+}$- 
induced fluorescence enhancement of 200 -fold in a manner similar to that discussed for 5 .

Upto now, we have discussed structures which all contain a 1-aminonaphthalene core. Further structural space can be explored by proceeding to compounds $\mathbf{1 5}$ and $\mathbf{1 6 .}$ Since the fluorescence switching behaviour of these and/or close relatives are available in the literature, ${ }^{5,7,27,64}$ it is sufficient to mention that these satisfy the classical PET system design of the 'fluorophore-spacer-receptor' model. Compounds 11-13 represent further movement along this mutational path. Naphthalene-1,8;4,5diimides of this type have received much attention as electron deficient $\pi$-systems for catenane construction, whether by direct ${ }^{65}$ or dynamic combinatorial ${ }^{66}$ methods. Stacking of these fluorophores has also resulted in a sensing application. ${ }^{67}$ Compound $\mathbf{1 1}$ is known and the quenching of its weak fluorescence by $\mathrm{Fe}^{3+}$ has been noted as well. $^{51}$

Table 2. Various parameters for 11-13, determined via pH-dependent uv-visible absorption and fluorescence spectroscopy. ${ }^{\mathrm{a}}$

\begin{tabular}{|l|l|l|l|}
\hline Parameter & $\mathbf{1 1}$ & $\mathbf{1 2}$ & $\mathbf{1 3}$ \\
\hline$\lambda_{\text {Abs }}$ & $343,360,381$ & $342,361,382$ & $342,361,382$ \\
\hline $\log \varepsilon^{\mathrm{b}}$ & $4.10,4.30,4.40$ & $4.12,4.32,4.44$ & $4.08,4.27,4.36$ \\
\hline$\lambda_{\text {Flu }^{c}}$ & 392,413 & 394,413 & 396,413 \\
\hline$\phi_{\text {Flu.acid }}{ }^{\mathrm{d}}$ & 0.15 & 0.16 & 0.18 \\
\hline$\phi_{\text {Flu.base }}{ }^{\mathrm{d}}$ & 0.007 & 0.010 & 0.011 \\
\hline FE $^{\mathrm{e}}$ & 21 & 16 & 17 \\
\hline pK $_{\mathrm{a}}{ }^{\mathrm{f}}$ & 7.2 & 5.1 & 8.4 \\
\hline
\end{tabular}

a. $10^{-5} \mathrm{M}$ in methanol:water (1:4, v/v). Fluorescence emission spectra are obtained by excitation at $\lambda_{\text {Abs. }}$. The subscripts 'acid' and 'base' in some of the parameters refer to the limiting value of a given parameter when the acid or base condition is increased respectively. The absorption spectral parameters are essentially $\mathrm{pH}$-independent under our conditions.

b. $\varepsilon$ in $\mathrm{M}^{-1} \mathrm{~cm}^{-1}$.

c. Essentially $\mathrm{pH}$-independent under our conditions.

d. uncertainty $=0.001$ or $10 \%$ whichever is the larger.

e. $\mathrm{H}^{+}$-induced fluorescence enhancement factor $=\phi_{\text {Flu.acid }} / \phi_{\text {Flu.base }}$.

f. obtained by analyzing the $\mathrm{pH}$ dependence of the fluorescence intensity $\left(\mathrm{I}_{\mathrm{Flu}}\right)$ or fluorescence quantum yield $\left(\phi_{\text {Flu }}\right)$ at a given wavelength according to the equation $\log \left[\left(\phi_{\text {Flu.acid }}-\phi_{\text {Flu }}\right) /\left(\phi_{\text {Flu }}-\phi_{\text {Flu.base }}\right)\right]=\mathrm{pH}-$ $\mathrm{pK}_{\mathrm{a}},{ }^{54}$ Uncertainty $=0.1$.

Table 2 summarizes the results for compounds 11-13. There is virtually no $\mathrm{pH}$ dependence in all of the absorption and emission spectral parameters except for the fluorescence quantum yield, as is known for ideal fluorescent PET systems. ${ }^{46}$ The $\mathrm{pH}$ dependent fluorescence spectra for $\mathbf{1 1}$ are collected in Figure 2 . Since the $\pi$-systems are rather symmetrical in 11-13, there is no ICT character in the excited state so that no electrostatic perturbation is caused by the protonation of the receptor situated across the oligomethylene spacer. The $\mathrm{H}^{+}$-induced $\mathrm{FE}$ values are substantially large (ca. 20) in all three cases, in spite of the relatively electron-poor morpholine receptor within 12 and the rather long trimethylene spacer in 13. A reason for this is the rather large driving force for PET in these systems owing to the electron deficiency of the fluorophore. In the instance of $\mathbf{1 1}$, the application of the Weller equation ${ }^{68}$ produces $\Delta \mathrm{G}_{\mathrm{PET}}=-1.8 \mathrm{eV}$. The calculation takes the excited state energy of the 
naphthalenediimide to be $3.2 \mathrm{eV}$ (calculated from the mean of the $0-0$ band wavelengths in absorption and emission in Table 2), its reduction potential to be -0.70 $\mathrm{V}^{65}$ and the oxidation potential of trimethylamine to be $0.76 \mathrm{~V}^{69}$ (while ignoring solvent effects).

The classical physical organic chemistry interpretation ${ }^{70}$ applies to the structural correlation of the $\mathrm{pK}_{\mathrm{a}}$ values found for the various compounds. Thus, the more electron-rich diethylamino unit within 3 has a higher value (8.9) than that found for the dimethylamino unit within 4 (8.3). Closer positioning of the methylamino receptor within 5 or 9 to the electron-withdrawing 4-amino group owing to the piperazine ring produces the lowest $\mathrm{pK}_{\mathrm{a}}$ value (7.3-7.4) observed in this study. The $\mathrm{pK}_{\mathrm{a}}$ and $\mathrm{pK}_{\mathrm{a}}$ ' values are identical within experimental error in all available cases (Table 1) since the protonation occurs at a receptor which is external to the fluorophore where the excitation resides. ${ }^{71}$ The lowest $\mathrm{pK}_{\mathrm{a}}$ ' value (5.1 for compound 12 ) found during this work arises for the morpholino unit containing the electron-withdrawing oxygen. Another contributor is the presence of the electron-withdrawing imide unit just two methylene groups away.

\section{Summary and conclusions}

We can conclude that steric preferences in the naphthalenic series can shift the mechanism of $\mathrm{H}^{+}$-induced fluorescence switching between PET and twisted ICT types. The PET mechanism requires an extra-fluorophoric amino receptor to deliver the electron, whereas the twisted ICT pathway relies on the twisting of an aromatic C-N bond within the fluorophore $\pi$-system. The extra-fluorophoric amino receptor serves as a cationically chargeable unit so that the twisted ICT excited state can be destabilized, thus weakening this deactivation channel. So we see that PET is directly influenced by amine protonation whereas twisted ICT pathway is controlled only via an electrostatic effect from some distance away. Unsurprisingly, PET designs are frequently found within sensing ${ }^{42-45}$ and $\operatorname{logic}^{72-76}$ systems. Careful attention to structural details will be required if twisted ICT mechanisms are to be similarly incorporated.

\section{Acknowledgements}

The Engineering and Physical Sciences Research Council, UK and Department of Employment and Learning, Northern Ireland are thanked for support.

\section{References}

1. B. M. Krasovitskii and B. M. Bolotin, Organic Luminescent Materials VCH, Weinheim, 1989.

2. A. P. de Silva, H. Q. N. Gunaratne, J. -L. Habib-Jiwan, C. P. McCoy, T. E. Rice and J. -P. Soumillion, New fluorescent model compounds for the study of photoinduced electron transfer; the influence of a molecular electric field, Angew. Chem. Int. Ed. Engl. 1995, 34, 1728-1731.

3. A. P. de Silva, H. Q. N. Gunaratne, T. Gunnlaugsson and P. L. M. Lynch, Fluorescent PET(photoinduced electron transfer) sensors for protons with an internal reference channel, New J. Chem. 1996, 20, 871-880.

4. A. P. de Silva, H. Q. N. Gunaratne and T. Gunnlaugsson, Fluorescent PET (photoinduced electron transfer) reagents for thiols, Tetrahedron Lett. 1998, 39, 5077 5080 . 
5. L. M. Daffy, A. P. de Silva, H. Q. N. Gunaratne, C. Huber, P. L. M. Lynch, T. Werner and O. S. Wolfbeis, Arenedicarboximide building blocks for fluorescent photoinduced electron transfer $\mathrm{pH}$ sensors applicable with different media and communication wavelengths, Chem. Eur. J. 1998, 4, 1810-1815.

6. A. P. de Silva and T. E. Rice, A small supramolecular system which emulates the unidirectional, path-selective photoinduced electron transfer (PET) of the bacterial photosynthetic reaction centre (PRC), Chem. Commun. 1999, 163-164.

7. B. Ramachandram, G. Saroja, N. B. Sankaran and A. Samanta, Unusually high fluorescence enhancement of some 1,8-naphthalimide derivatives induced by transition metal salts, J. Phys. Chem. B 2000, 104, 11824-11832.

8. R. T. Hayes, M. R. Wasielewski and D. Gosztola, Ultrafast photoswitched charge transmission through the bridge molecule in a donor-bridge-acceptor system, J. Am. Chem. Soc. 2000, 122, 5563-5567.

9. H. Tian, J. Gan, K. C. Chen, Q. L. Song and X. Y. Hou, Positive and negative fluorescent imaging induced by naphthalimide polymers, J. Mater. Chem. 2002, 12, 1262-1267.

10. T. Gunnlaugsson, M. Nieuwenhuyzen, L. Richard and V. Thoss, Novel sodiumselective fluorescent PET and optically based chemosensors: Towards $\mathrm{Na}^{+}$

determination in serum, J. Chem. Soc. Perkin Trans. 2 2002, 141-150.

11. I. Grabchev, X. H. Qian, Y. Xiao and R. Zhang, Novel heterogeneous PET fluorescent sensors selective for transition metal ions or protons: polymers regularly labelled with naphthalimide, New J. Chem. 2002, 26, 920-925.

12. T. Gunnlaugsson, T. C. Lee and R. Parkesh, A highly selective and sensitive fluorescent PET (photoinduced electron transfer) chemosensor for Zn(II), Org. Biomol. Chem. 2003, 1, 3265-3267.

13. M. Licchelli, A. O. Biroli, A. Poggi, D. Sacchi, C. Sangermani and M. Zema, Excimer emission induced by metal ion coordination in 1,8-naphthalimide-tethered iminopyridine ligands, Dalton Trans. 2003, 4537-4545.

14. I. Grabchev, J. -M. Chovelon and X. H. Qian, A polyamidoamine dendrimer with peripheral 1,8-naphthalimide groups capable of acting as a PET fluorescent sensor for metal cations, New J. Chem. 2003, 27, 337-340.

15. A. P. de Silva, A. Goligher, H. Q. N. Gunaratne and T. E. Rice, The pH-dependent fluorescence of pyridylmethyl-4-amino-1,8-naphthalimides, ARKIVOC 2003, part vii, 229-243.

16. L. H. Jia, Y. Zhang, X. F. Guo and X. H. Qian, A novel chromatism switcher with double receptors selectively for $\mathrm{Ag}^{+}$in neutral aqueous solution: 4,5-

diaminoalkeneamino-N-alkyl-1,8-naphthalimides, Tetrahedron Lett. 2004, 45, 39693973.

17. D. W. Cui, X. H. Qian, F. Y. Liu and R. Zhang, Novel fluorescent pH sensors based on intramolecular hydrogen bonding ability of naphthalimide, Org. Lett. 2004, 6, 2757-2760.

18. X. F. Guo, X. H. Qian and L. H. Jia, A highly selective and sensitive fluorescent chemosensor for $\mathrm{Hg}^{2+}$ in neutral buffer aqueous solution, J. Am. Chem. Soc. 2004, 126, 2272-2273.

19. J. B. Wang, Y. Xiao, Z. C. Zhang, X. H. Qian, Y. Y. Yang and Q. Xu, A pHresistant Zn(II) sensor derived from 4-aminonaphthalimide: design, synthesis and intracellular applications, J. Mater. Chem. 2005, 15, 2836-2839.

20. J. B. Wang and X. H. Qian, Two regioisomeric and exclusively selective Hg(II) sensor molecules composed of a naphthalimide fluorophore and an ophenylenediamine derived triamide receptor, Chem. Commun. 2006, 109-111. 
21. E. Tamanini, A. Katewa, L. M. Sedger, M. H. Todd and M. Watkinson, A synthetically simple, click-generated cyclam-based zinc(II) sensor, Inorg. Chem. 2009, 48, 319-324.

22. X. H. Qian, Y. Xiao, Y. F. Xu, X. F. Guo. J. H. Qian and W. P. Zhu, "Alive" dyes as fluorescent sensors: fluorophore, mechanism, receptor and images in living cells, Chem. Commun. 2010, 6418-6436.

23. Z. C. Xu, K. H. Baek, H. N. Kim, J. N. Cui, X. H. Qian, D. R. Spring, I. J. Shin and J. Yoon, $\mathrm{Zn}^{2+}$-triggered amide tautomerization produces a highly $\mathrm{Zn}^{2+}$-selective, cell-permeable, and ratiometric fluorescent sensor, J. Am. Chem. Soc. 2010, 132, 601610.

24. P. A. Panchenko, Y. V. Fedorov, V. P. Perevalov, G. Jonusauskas and O. A. Fedorova, Cation-dependent fluorescent properties of naphthalimide derivatives with N-benzocrown ether fragment, J. Phys. Chem. A 2010, 114, 4118-4122.

25. J. L. Liu and A. P. de Silva, Path-selective photoinduced electron transfer (PET) in a membrane-associated supramolecular system, Inorg. Chim. Acta 2012, 381, 243246.

26. A. S. Lukas, P. J. Bushard and M. R. Wasielewski, Ultrafast molecular logic gate based on optical switching between two long-lived radical ion pair states, J. Am.

Chem. Soc. 2001, 123, 2440-2441.

27. M. de Sousa, M. Kluciar, S. Abad, M. A. Miranda, B. de Castro and U. Pischel, An inhibit (INH) molecular logic gate based on 1,8-naphthalimide-sensitised europium luminescence, Photochem. Photobiol. Sci. 2004, 3, 639-642.

28. D. H. Qu, Q. C. Wang and H. Tian, A half adder based on a photochemically driven [2]rotaxane, Angew. Chem. Int. Ed. Engl. 2005, 44, 5296-5299.

29. J. H. Qian, Y. F. Xu, X. H. Qian, J. B. Wang and S. Y. Zhang, Effects of anionic surfactant SDS on the photophysical properties of two fluorescent molecular sensors, J. Photochem. Photobiol. A: Chem. 2008, 200, 402-409.

30. J. H. Qian, X. H. Qian, Y. F. Xu and S. Y. Zhang, Multiple molecular logic functions and molecular calculations facilitated by surfactant's versatility, Chem. Commun. 2008, 4141-4143.

31. J. B. Jiang, B. Leng, X. Xiao, P. Zhao and H. Tian, "Off-On-Off" fluorescent proton switch synthesized by RAFT polymerization, Polymer 2009, 50, 5681-5684.

32. R. Ferreira, P. Remon and U. Pischel, Multivalued logic with a tristable fluorescent switch, J. Phys. Chem. C 2009, 113, 5805-5811.

33. J. H. Qian, X. H. Qian and Y. F. Xu, Selective and sensitive chromo- and fluorogenic dual detection of anionic surfactants in water based on a pair of "on-offon" fluorescent sensors, Chem. Eur. J. 2009, 15, 319-323.

34. A. J. Moro, P. J. Cywinski, S. Korsten and G. J. Mohr, An ATP fluorescent chemosensor based on a $\mathrm{Zn}(\mathrm{II})$-complexed dipicolylamine receptor coupled with a naphthalimide chromophore, Chem. Commun. 2010, 46, 1085-1087.

35. U. Pischel, V. D. Uzunova, P. Remon and W. M. Nau, Supramolecular logic with macrocyclic input and competitive reset, Chem. Commun. 2010, 46, 2635-2637. 36. J. H. Qian, Y. F. Xu, S. T. Zhang and X. H. Qian, A supramolecular off-on fluorescent switch and IMPLICATION logic gate for detection of cationic surfactant, J. Fluoresc. 2011, 21, 1015-1020.

37. V. F. Pais, P. Remon, D. Collado, J. Andreasson, E. Perez-Inestrosa and U.

Pischel, OFF-ON-OFF fluorescence switch with T-latch function, Org. Lett. 2011, 13, 5572-5575. 
38. H. He, M. Mortellaro, M. J. P. Leiner, S. T. Young, R. J. Fraatz and J. Tusa, A fluorescent chemosensor for sodium based on photoinduced electron transfer, Anal. Chem. 2003, 75, 549-555.

39. H. He, M. Mortellaro, M. J. P. Leiner, R. J. Fraatz and J. Tusa, A fluorescent sensor with high selectivity and sensitivity for potassium in water, J. Am. Chem. Soc. 2003, 125, 1468-1469.

40. J. K. Tusa and H. He, Critical care analyzer with fluorescent optical chemosensors for blood analytes, J. Mater. Chem. 2005, 15, 2640-2647.

41. H. R. He, K. Jenkins and C. Lin, A fluorescent chemosensor for calcium with excellent storage stability in water, Anal. Chim. Acta 2008, 611, 197-204.

42. R. A. Bissell, A. P. de Silva, H. Q. N. Gunaratne, P. L. M. Lynch, G. E. M. Maguire, C. P. McCoy and K. R. A. S. Sandanayake, Fluorescent PET(photoinduced electron transfer) sensors, Top. Curr. Chem. 1993, 168, 223-264.

43. A. W. Czarnik, Chemical communication in water using fluorescent chemosensors, Acc. Chem. Res. 1994, 27, 302-308.

44. A. P. de Silva, H. Q. N. Gunaratne, T. Gunnlaugsson, A. J. M. Huxley, C. P. McCoy, J. T. Rademacher and T. E. Rice, Signalling recognition events with fluorescent sensors and switches, Chem. Rev. 1997, 97, 1515-1566.

45. A. P. de Silva and S. Uchiyama, Molecular logic gates and luminescent sensors based on photoinduced electron transfer (PET), Top. Curr. Chem. 2011, 300, 1-28.

46. R. A. Bissell, A. P. de Silva, H. Q. N. Gunaratne, P. L. M. Lynch, G. E. M.

Maguire and K. R. A. S. Sandanayake, Molecular fluorescent signalling with 'fluorspacer-receptor' systems; approaches to sensing and switching devices via supramolecular photophysics, Chem. Soc. Rev. 1992, 21, 187-195.

47. A. P. de Silva, T. P. Vance, M. E. S. West and G. D. Wright, Bright molecules with sense, logic, numeracy and utility, Org. Biomol. Chem. 2008, 6, 2468-2480. 48. E. W. Miller, J. Y. Lin, E. P. Frady, P. A. Steinbach, W. B. Kristan and R. Y. Tsien, Optically monitoring voltage in neurons by photoinduced electron transfer through molecular wires, Proc. Natl. Acad. Sci. USA 2012, 109, 2114-2119.

49. X. H. Qian, Z. H. Zhu and K. C. Cheng, The synthesis, application and prediction of Stokes shift in fluorescent dyes derived from 1,8-naphthalic anhydride, Dyes Pigm. 1989, 11, 13-20.

50. M. S. Alexiou, V. Tychopoulos, S. Ghorbanian, J. H. P. Tyman, R. G. Brown and P. I. Brittain, The uv-visible absorption and fluorescence of some substituted 1,8naphthalimides and naphthalic anhydrides, J. Chem. Soc. Perkin Trans. 2 1990, 837842.

51. M. S. Refat, I. Grabchev, J. -M. Chovelon and G. Ivanova, Spectral properties of new $N, N$-bis-alkyl-1,4,6,8-naphthalenediimide complexes, Spectrochim. Acta A 2006, 64, 435-441.

52. Indicators (Ed. E. Bishop) Pergamon, Oxford, 1972.

53. K. A. Connors, Binding Constants: The Measurement of Complex Stability Wiley, New York, 1987.

54. R. A. Bissell, E. Calle, A. P. de Silva, S. A. de Silva, H. Q. N. Gunaratne, J. -L. Habib-Jiwan, S. L. A. Peiris, R. A. D. D. Rupasinghe, T. K. S. D. Samarasinghe, K. R. A. S. Sandanayake and J. -P. Soumillion, Luminescence and charge transfer. part 2. Aminomethyl anthracene derivatives as fluorescent PET(photoinduced electron transfer) sensors for protons, J. Chem. Soc. Perkin Trans. 2 1992, 1559-1564.

55. R. W. Alder, Strain effects on amine basicities, Chem. Rev. 1989, 89, 1215-1223. 
56. Z. R. Grabowski, K. Rotkiewicz, A. Siemiarczuk, D. J. Cowley and W. Baumann, Twisted intra-molecular charge-transfer states (TICT) - new class of excited-states with a full charge separation, Nouveau J. Chim. New J. Chem. 1979, 3, 443-454. 57 . W. Rettig, Photoinduced charge separation via twisted intramolecular chargetransfer states, Top. Curr. Chem. 1994, 169, 253-299.

58. W. Rettig, Charge separation in excited-states of decoupled systems - TICT compounds and implications regarding the development of new laser-dyes and the primary processes of vision and photosynthesis, Angew. Chem. Int. Ed. Engl. 1986, 25, 971-988.

59. Z. R. Grabowski and J. Dobkowski, Twisted intramolecular charge-transfer (TICT) excited-states - energy and molecular-structure, Pure Appl. Chem. 1983, 55, 245-252.

60. A. P. de Silva and R. A. D. D. Rupasinghe, A new class of fluorescent pH indicators based on photoinduced electron transfer, J. Chem. Soc. Chem. Commun. 1985, 1669-1670.

61. J. A. Gan, K. C. Chen, C. P. Chang and H. Tian, Luminescent properties and photo-induced electron transfer of naphthalimides with piperazine substituent, Dyes Pigm. 2003, 57, 21-28.

62. Y. Q. Gao and R. A. Marcus, Theoretical investigation of the directional electron transfer in 4-aminonaphthalimide compounds, J. Phys. Chem. A 2002, 106, 19561960.

63. A. P. de Silva, H. Q. N. Gunaratne, P. L. M. Lynch, A. L. Patty and G. L. Spence Luminescence and charge transfer. Part 3. The use of chromophores with ICT(internal charge transfer) excited states in the construction of fluorescent PET(photoinduced electron transfer) $\mathrm{pH}$ sensors and related absorption $\mathrm{pH}$ sensors with aminoalkyl side chains, J. Chem. Soc. Perkin Trans. 2 1993, 1611-1616.

64. B. Ramachandram, N. B. Sankaran, R. Karmakar, S. Saha and A. Samanta, Fluorescence signalling of transition metal ions by multi-component systems comprising 4-chloro-1,8-naphthalimide as fluorophore, Tetrahedron 2000, 56, 70417044.

65. D. G. Hamilton, M. Montalti, L. Prodi, M. Fontani, P. Zanello and J. K. M. Sanders, Photophysical and electrochemical characterisation of the interactions between components in neutral pi-associated [2]catenanes, Chem. Eur. J. 2000, 6, 608-617.

66. F. B. L. Cougnon, N. A. Jenkins, G. D. Pantos and J. K. M. Sanders, Templated dynamic synthesis of a [3]catenane, Angew. Chem. Int. Ed. 2012, 51, 1443-1447. 67. H. N. Lee, Z. C. Xu, S. K. Kim, K. M. K. Swamy, Y. M. Kim, S. J. Kim and J. Yoon, Pyrophosphate-selective fluorescent chemosensor at physiological $\mathrm{pH}$ : Formation of a unique excimer upon addition of pyrophosphate, J. Am. Chem. Soc. 2007, 129, 3828-3829.

68. A. Weller, Electron-transfer and complex formation in the excited state, Pure Appl. Chem. 1968, 16, 115-124.

69. H. Siegerman, Oxidation and reduction potentials, in Technique of Electroorganic Synthesis Part II (Ed. N. L. Weinberg) Wiley, New York, 1975, pp. 667-1056.

70. E. V. Anslyn and D. A. Dougherty, Modern Physical Organic Chemistry University Science Books, Sausalito CA, 2005.

71. J. F. Ireland and P. A. H. Wyatt, Acid-base properties of electronically excited states of organic molecules, Adv. Phys. Org. Chem. 1976, 12, 132-223.

72. A. P. de Silva, H. Q. N. Gunaratne and C. P. McCoy, A molecular photoionic AND logic gate based on fluorescent signalling, Nature 1993, 364, 42-44. 
73. A. P. de Silva and N. D. McClenaghan, Proof-of-principle of molecular-scale arithmetic, J. Am. Chem. Soc. 2000, 122, 3965-3966.

74. A. P. de Silva, Y. Leydet, C. Lincheneau and N. D. McClenaghan, Chemical approaches to nanometer-scale logic gates, J. Phys. Condensed Matter 2006, 18, S1847-S1872.

75. J. Andreasson and U. Pischel, Smart molecules at work-mimicking advanced logic operations, Chem. Soc. Rev. 2010, 39, 174-188.

76. A. P. de Silva, Molecular logic gate arrays, Chem. Asian J. 2011, 6, 750-766.

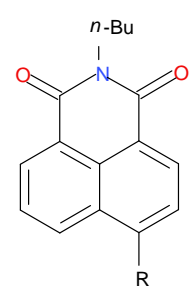

1; $\mathrm{R}=\mathrm{HNCH}_{2} \mathrm{CH}_{2} \mathrm{NEt}_{2}$ 2; $\mathrm{R}=\mathrm{Cl}$

3; $\mathrm{R}=\mathrm{MeNCH}_{2} \mathrm{CH}_{2} \mathrm{NEt}_{2}$ 4; $\mathrm{R}=\mathrm{MeNCH}_{2} \mathrm{CH}_{2} \mathrm{NMe}_{2}$ 5; $\mathrm{R}=\mathrm{N}\left(\mathrm{CH}_{2} \mathrm{CH}_{2}\right)_{2} \mathrm{NMe}$ 6; $\mathrm{R}=\mathrm{N}\left(\mathrm{CH}_{2} \mathrm{CH}_{2}\right)_{2} \mathrm{O}$

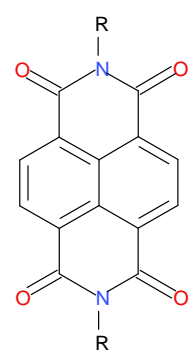

11; $\mathrm{R}=\mathrm{CH}_{2} \mathrm{CH}_{2} \mathrm{NMe}_{2}$

12; $\mathrm{R}=\mathrm{CH}_{2} \mathrm{CH}_{2} \mathrm{~N}\left(\mathrm{CH}_{2} \mathrm{CH}_{2}\right)_{2} \mathrm{O}$

13; $\mathrm{R}=\mathrm{CH}_{2} \mathrm{CH}_{2} \mathrm{CH}_{2} \mathrm{NMe}_{2}$<smiles>O=C1c2cccc3c(N4CCOCC4)ccc(c23)C(=O)N1c1ccccc1</smiles>

7; $\mathrm{R}=\mathrm{CH}_{2} \mathrm{CH}_{2} \mathrm{NEt}_{2}$

8; $\mathrm{R}=\mathrm{CH}_{2} \mathrm{CH}_{2} \mathrm{~N}\left(\mathrm{CH}_{2} \mathrm{CH}_{2}\right)_{2} \mathrm{O}$

9; $\mathrm{R}=\mathrm{N}\left(\mathrm{CH}_{2} \mathrm{CH}_{2}\right)_{2} \mathrm{NMe}$ 10; $\mathrm{R}=\mathrm{N}\left(\mathrm{CH}_{2} \mathrm{CH}_{2}\right)_{2} \mathrm{O}$

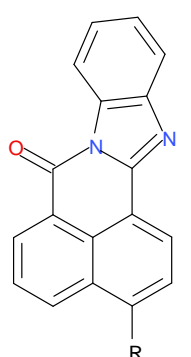

15; $\mathrm{R}=\mathrm{Cl}$

$16 ; \mathrm{R}=\mathrm{H}$ 




Figure 1. Fluorescence emission spectra of $\mathbf{4}$ as a function of $\mathrm{pH}$. $\mathrm{pH}$ values in order of decreasing fluorescence intensity; 4.1, 5.1, 7.5, 7.9, 8.3, 8.7, 9.0, 9.3 and 9.7.



Figure 2. Fluorescence emission spectra of $\mathbf{1 1}$ as a function of $\mathrm{pH}$. $\mathrm{pH}$ values in order of decreasing fluorescence intensity; 4.6, 6.1, 6.7, 7.0, 7.3, 7.5, 7.9 and 8.9. 